\title{
ANALISIS KEMAMPUAN MEMBAYAR ( CAPACITY TO REPAYMENT ) DALAM MENGAMBIL KPR BTN BERSUBSIDI IB DI BANK TABUNGAN NEGARA KANTOR CABANG SYARIAH BOGOR
}

\author{
Asti Marlina dan Oki \\ Program Studi Keuangan dan Perbankan Fakultas Ekonomi dan Bisnis \\ Universitas Ibn Khaldun \\ asti@uika-bogor.ac.id
}

\begin{abstract}
Abstrak
Pembiayaan merupakan aktivitas bank Syariah dalam menyalurkan dana kepada pihak selain bank berdasarkan prinsip Syariah. Penyaluran dana dalam bentuk pembiayaan didasarkan pada kepercayaan yang diberikan oleh pemilik dana kepada pengguna dana. Dalam mengajukan pembiayaan, perlu dilakukan analisis terhadap kemampuan nasabah dalam melakukan pembayaran. Analisis yang dilakukan adalah berprinsip $6 \mathrm{C}$, yaitu Character, Capacity, Capital, Collateral, Condition of economi, Constraint. Salah satu analisis yang dianggap penting adalah penilaian tentang kapasitas Kemampuan Membayar ( Capacity to Repayment ) Nasabah. Untuk melakukan analisis ini, yang dilakukan oleh bagian financing analyst dalam menganalisis Kemampuan ( Capacity ) Nasabah adalah dengan cara melihat KTP untuk mengetahui karakter nasabah dari hasil IDEB / BI Checking / ID BI dan untuk mengetahui jumlah angsuran perbulan berdasarkan pembiayaan yang telah diterima sebelumnya, melihat Kartu Keluarga untuk mengetahui jumlah tanggungan, sehingga bisa memperkirakan pengeluaran pribadi / keluarga dalam 1 bulan, melihat buku nikah untuk mengetahui status pernikahan, melihat Slip Gaji + copy rekening koran untuk mengetahui dan memastikan Nominal Gaji / Penghasilan yang diterima perbulan, melihat Surat keterangan kerja untuk memastikan Posisi, Jabatan dan Tempat kerja Nasabah.
\end{abstract}

Kata Kunci : Pembiayaan, Analisis, Capacity

\section{Pendahuluan}

\section{Latar Belakang}

PT. Bank Tabungan Negara (Persero)

Tbk. merupakan Bank milik pemerintah Indonesia yang sudah puluhan tahun memfokuskan dan meningkatkan layanan jasa dan produknya kepada masyarakat Indonesia dalam pemberian Kredit Pemilikan Rumah (KPR). PT. Bank Tabungan Negara Syariah (Persero) Tbk. sebagai Bank Syariah yang didirikan dan dibentuk oleh PT. Bank Tabungan Negara (Persero) Tbk. dengan produk unggulannya KPR Syariah.
BTN Syariah tidak jauh beda dengan bank konvensional yaitu berfungsi sebagai lembaga intermediasi (intermediary institution), yaitu mengerahkan dana (uang) dari masyarakat dan menyalurkan kembali dana - dana (uang - uang) tersebut kepada masyarakat yang membutuhkannya dalam bentuk fasilitas pembiayaan. Bedanya bank Syariah melakukan kegiatan usahanya tidak berdasarkan bunga atau bebas bunga, tetapi berdasarkan prinsip pembagian keuntungan dan kerugian. 
Salah satu produk KPR Syariah di PT. Bank Tabungan Negara Syariah (Persero) Tbk. yaitu KPR BTN Bersubsidi iB, diperuntukan bagi pemohon perorangan yang akan membeli rumah dari bank, yang dibangun oleh pengembang sesuai dengan kebutuhan dari nasabah.

Dalam penilaiannya, Bank Syariah melakukan analisa. Begitu pula dengan ukuran - ukuran yang ditetapkan sudah menjadi standar penilaian setiap bank Syariah. Biasanya penilaian yang harus dilakukan oleh bank Syariah untuk mendapatkan nasabah yang benar - benar menguntungkan, diantaranya dilakukan dengan Analisis 6C.

Adapun Analisa 6C adalah :

1. Character

2. Capacity

3. Capital

4. Collateral

5. Condition of economi

6. Constraint

Salah satu alat analisis adalah penilaian tentang kapasitas Kemampuan Membayar (Capacity to Repayment) Nasabah, yaitu untuk melakukan penganalisaan Kemampuan Membayar (Capacity to Repayment) dalam mengambil KPR Bersubsidi iB di Bank Tabungan Negara Kantor Cabang Syariah Bogor.

\section{Rumusan Masalah}

Berdasarkan latar belakang diatas, maka ruang lingkup penulisan Karya Ilmiah ini diantaranya:

1. Bagaimana Cara Menganalisis Kemampuan Membayar (Capacity to Repayment) dalam mengambil KPR BTN Bersubsidi iB di Bank Tabungan Negara Kantor Cabang Syariah Bogor?

2. Bagaimana Cara Perhitungan Pembayaran KPR BTN Bersubsidi iB di
Bank Tabungan Negara Kantor Cabang Syariah Bogor?

\section{Tujuan Penelitian}

Berdasarkan ruang lingkup, maka tujuan dari penulisan Karya Ilmiah ini diantaranya :

1. Untuk Mengetahui Analisa Kemampuan Membayar (Capacity to Repayment) dalam mengambil KPR BTN Bersubsidi iB di Bank Tabungan Negara Kantor Cabang Syariah Bogor.

2. Untuk Mengetahui Perhitungan Pembayaran KPR BTN Bersubsidi iB di Bank Tabungan Negara Kantor Cabang Syariah Bogor.

\section{Manfaat Penelitian}

Sedangkan manfaat dari penulisan Karya Ilmiah ini diantaranya :

1. Bagi BTN Kantor Cabang Syariah Bogor Karya Ilmiah ini diharapkan dapat memberikan informasi dan pengetahuan dalam rangka mengambil keputusan kebijakan untuk mempertahankan dan mengkuatkan kepercayaan nasabah serta meningkatkan nasabah baru.

2. Bagi Penulis

Karya Ilmiah ini diharapkan saya dapat menambah ilmu dan mengamalkan (mempraktekkan) ilmu yang telah didapat dibangku kuliah selama ini, serta memenuhi salah satu syarat memperoleh gelar Ahli Madya pada Fakultas Ekonomi dan Bisnis, di Universitas Ibn Khaldun Bogor.

3. Bagi Pihak lain

Karya Ilmiah ini diharapkan dapat dijadikan sebagai sumber ilmu Analisis Kemampuan Membayar (Capacity to Repayment) dalam mengambil KPR Bersubsidi iB di Bank Tabungan Negara Kantor Cabang Syariah Bogor. 


\section{Kajian Teori}

\section{Bank syariah}

Pengertian bank menurut UU No 7 tahun 1992 adalah badan usaha yang menghimpun dari masyarakat dalam bentuk simpanan dan menyalurkannya kepada masyarakat dalam rangka meningkatkan taraf hidup rakyat banyak. (Lukman Dandawijaya, Manajemen Perbankan Syariah, Jakarta : Ghalia Indonesia, 2001, hal 25). Bank Syariah berarti bank yang tata cara operasionalnya didasari dengan tata cara Islam yang mengacu kepada ketentuan Al - Qur'an dan Al - Hadist.

\section{Jenis - jenis Bank Syariah}

1. Bank Umum Syariah (B U S)

Bank Umum Syariah adalah bank Syariah yang dalam kegiatannya memberikan jasa dalam lalu lintas pembayaran. B U S dapat berusaha sebagai bank devisa dan bank non devisa.

\section{Unit Usaha Syariah ( $U$ U S)}

Unit Usaha Syariah adalah unit kerja dari kantor pusat bank umum konvensional yang berfungsi sebagai kantor induk dari kantor atau unit yang melaksanakan kegiatan usaha berdasarkan prinsip Syariah.

3. Bank Pembiayaan Rakyat Syariah (BPRS)

Bank Pembiayaan Syariah adalah bank Syariah yang dalam kegiatannya tidak memberikan jasa dalam lalu lintas pembayaran. Pembiayaan

\section{KPR Syariah ( Kredit Pemilikan Rumah ) Pengertian KPR Syariah}

KPR Syariah adalah salah satu produk pembiayaan ( financing ) dari bank Syariah yang membantu keluarga Indonesia untuk dapat mewujudkan impiannya untuk memiliki rumah idamannya sendiri bagi keluarga tercinta.

\section{Jenis - jenis KPR Syariah}

Di Indonesia, saat ini dikenal dua jenis KPR Syariah, yaitu sebagai berikut :
1. KPR Syariah Subsidi, yaitu semua kredit yang diperuntukkan bagi masyarakat berpenghasilan menengah ke bawah dalam rangka memenuhi kebutuhan perumahan atau perbaikan rumah yang telah dimiliki.

2. KPR Syariah Non Subsidi, yaitu suatu KPR Syariah yang diperuntukkan bagi masyarakat yang berpenghasilan menengah ke atas dalam rangka memenuhi kebutuhan perumahan atau perbaikan rumah yang telah dimiliki.

Analisis Kemampuan Membayar (Capacity to Repayment) dengan Prinsip Analisis 6C

Penerapan prinsip Analisis 6C dalam pemberian pembiayaan serta analisis yang mendalam terhadap calon nasabah, perlu dilakukan oleh bank Syariah agar bank tidak salah memilih dalam menyalurkan dananya sehingga dana yang disalurkan kepada nasabah dapat terbayar kembali sesuai dengan jangka waktu yang diperjanjikan. Analisis 6C, yaitu:

\section{a. Character}

Menggambarkan watak dan kepribadian calon nasabah. Bank Syariah perlu melakukan analisis terhadap karakter calon nasabah dengan tujuan untuk mengetahui bahwa calon nasabah mempunyai keinginan untuk memenuhi kewajiban membayar kembali pembiayaan yang telah diterima hingga lunas.

Cara yang perlu dilakukan oleh bank untuk mengetahui Character calon nasabah antara lain: BI Checking Bank Syariah dapat melakukan penelitian dengan melakukan BI Checking, yaitu melakukan penelitian terhadap calon nasabah dengan melihat data nasabah melalui komputer yang online dengan Bank Indonesia.

\section{b. Capacity}

Analisis terhadap Capacity ini ditunjukan untuk mengetahui kemampuan keuangan 
calon nasabah dalam memenuhi kewajibannya sesuai jangka waktu pembiayaan.

\section{c. Capital}

Capital atau modal yang perlu disertakan dalam objek pembiayaan perlu dilakukan analisis yang lebih mendalam.

\section{d. Collateral}

Merupakan agunan yang diberikan oleh calon nasabah atas pembiayaan yang diajukan. Agunan merupakan sumber pembayaran kedua.

e. Condition of Economy

Merupakan analisis terhadap kondisi perekonomian. Bank Syariah perlu mempertimbangkan sektor usaha calon nasabah dikaitkan dengan kondisi ekonomi.

\section{Metode Penelitian}

Kegiatan magang dilaksanakan dengan dua metode yaitu metode secara langsung dan metode secara tidak langsung. Metode secara langsung yang telah dilaksanakan selama magang meliputi kegiatan yang menyangkut

\section{Pembahasan}

\section{Cara Menganalisis Kemampuan Membayar (Capacity to Repayment) dalam mengambil KPR BTN Bersubsidi iB}

Studi kasus Analisis Kemampuan Membayar (Capacity to Repayment) dalam mengambil KPR Bersubsidi iB di Bank Tabungan Negara Kantor Cabang Syariah Bogor.

Bapak RUDI mengajukan Pembiayaan KPR Bersubsidi iB di BTN Kantor Cabang Syariah Bogor. Bapak RUDI berstatus Belum Menikah. Bapak RUDI memiliki History Pembiayaan (LUNAS, LUNAS LANCAR DENGAN KOLEKTABILITAS 1.) Bapak RUDI berpenghasilan tunggal (Single Income). Bapak RUDI bekerja Sebagai Manajer Operasional Retail di PT. Maju Pesat

\section{f. Constraint}

Dalam pemberian kredit, bank perlu juga mengetahui dan mempertimbangkan hambatan (constraint) yang mungkin muncul di lapangan. (Ismail, perbankan Syariah (Jakarta : Kencana, 2011), hlm : 120 - 126).

Bank Syariah akan memfokuskan beberapa prinsip antara lain character, capacity, dan collateral. Ketiga prinsip dasar pemberian pembiayaan ini dianggap sebagai faktor penting yang tidak dapat ditinggalkan sebelum mengambil keputusan. (Husein Umar, Research Methods and Banking (Jakarta: Gramedia, 2000) halaman 111).

aspek teknis dan manajerial, serta aspek khusus. Sementara itu metode tidak langsung dilaksanakan selama magang adalah mengumpulkan data sekunder dan studi pustaka.

Tbk. Alamat kantor Bapak RUDI di Jl. Jendral Sudirman no. 10 Bogor Utara.

Bapak RUDI memiliki penghasilan Sebagai berikut :

Gaji Pokok Bapak RUDI perbulan sebesar Rp. 3.500.000,-. Tambahan Penghasilan Bapak RUDI perbulan sebesar Rp. 500.000,-. TOTAL Penghasilan Bapak RUDI perbulan sebesar Rp. 4.000.000,-. Masa kerja Bapak RUDI 5 Tahun dan Bapak RUDI sudah Pegawai Tetap. Usia Bapak RUDI 27 Tahun. Usia Pensiun Bapak RUDI sampai dengan 55 Tahun. Jumlah Pegawai PT. Maju Pesat Tbk. Sebanyak 1100 orang. PT. Maju Pesat Tbk. Bergerak dibidang Retail. Konfirmasi dengan ibu ULFI sebagai HRD di PT. Maju Pesat Tbk. / no. telpon PT. Maju Pesat Tbk. 021 - 75423321. 
MAKSIMAL

JANGKA

WAKTU

PEMBIAYAAN KPR 20 TAHUN.

Biaya Angsuran Lain perbulan sebesar Rp. 900.000,- (Hasil dari BI Checking). Pengeluaran keluarga perbulan sebesar $\mathrm{Rp}$. 1.500.000,-.

PERHITUNGAN RPC :

$R P C$ Max $70 \%$ dari sisa penghasilan bersih $\mathrm{x}$ ( total penghasilan perbulan pemohon - total dari Biaya Angsuran lain + pengeluaran keluarga )

$70 \%$ x (Rp. 4.000.000,- - Rp. 2.400.000,-) $=$ Rp. 1.600.000,- (B) x 70\% = Rp. 1.120.000,-. (Batas maksimal Angsuran yang bisa BTN Kantor Cabang Syariah Bogor berikan kepada Bapak Rudi / pemohon.)

Kondisi Agunan READY STOCK Blok / Kavling / No. Agunan Perum Bogor Indah Permai Blok E No. 77. Luas Bangunan / Luas Tanah 28 / 60.

HARGA JUAL = Rp. 265.999.920,-. (C)

UM $($ margin \% $)=$ Rp. 6.649.996,-.

PERMOHONAN = Rp. 133.000.000,-.

KESIMPULAN DAN REKOMENDASI dari Studi kasus Analisis Kemampuan Membayar (Capacity to Repayment) bernama Bapak RUDI.

Maksimum Pembiayan sebesar Rp.

133.000.000,-. (D)

Jangka waktu sampai dengan 240 bulan / 20 tahun.

Angsuran perbulan sebesar Rp. 1.108.333,--

(A)

$R P C=0,6927$ / 69 (dalam bahasa BTN

Syariah Cabang Bogor.)

$L T V=0,9523 / 95$ (dalam bahasa BTN

Syariah Cabang Bogor.)

- Perkiraan usia pada saat lunas pembiayaan 47 tahun.

- Mohon pihak terkait untuk dipastikan legalitas sertipikat dan IMB, serta memastikan jangka waktu sertipikat jika SHGB terkait jangka waktu pembiayaan.
- Diusulkan untuk segera dilakukan penilian agunan dan pastikan persetujuan pembiayaan lebih kecil dari nilai jual cepat berdasarkan penilaian agunan oleh KJPP, apabila nilai jual cepat lebih kecil di banding persetujuan pembiayaan mohon untuk dilakukan analisa ulang terkait hasil penilaian agunan oleh KJPP.

- Mohon dilakukan dokumentasi akad baik foto / video dan dilampirkan dalam dokumen pokok.

- Mohon pihak terkait untuk dilakukan kelengkapan data / update data / berkas asli sesuai ketentuan sebelum realisasi.

- Agunan Wajib dilakukan Clearence terlebih dahulu dan agunan wajid diikat sempurna.

- Mohon dipastikan sebelum akad pembiayaan pemohon dapat dicover oleh asuransi jiwa maupun kebakaran.

- Mohon pihak terkait untuk memastikan bahwa agunan sudah jadi $100 \%$.

- Rumus :

RPC $($ Repayment Capacity $)=\mathrm{A}: \mathrm{B}$ LTV $($ Loan to Value $)=\mathrm{D}: \mathrm{C}$

- Catatan :

KPR Bersubsidi iB UM (Margin) minimal $5 \%$ dari Harga Jual.

RPC adalah Kapasitas Pembayaran Kembali ( Repayment Capacity ).

BTN Syariah Cabang Bogor RPC Max 70 $\%$ dari sisa Penghasilan Bersih.

Cara Divisi / Bagian financing analyst dalam menganalisis Kemampuan (Capacity) Nasabah dalam mengambil produk pembiyaan KPR Bersubsidi iB dengan :

a. Melihat KTP untuk mengetahui karakter nasabah dari hasil IDEB / BI Checking / ID BI dan untuk mengetahui jumlah angsuran perbulan berdasarkan pembiayaan yang telah diterima sebelumnya.

b. Melihat Kartu Keluarga untuk mengetahui jumlah tanggungan, sehingga bisa memperkirakan 
pengeluaran pribadi / keluarga dalam 1 bulan.

c. Melihat buku nikah untuk mengetahui status pernikahan.

d. Melihat Slip Gaji + copy rekening koran untuk mengetahui dan memastikan Nominal Gaji / Penghasilan yang diterima perbulan.

e. Melihat Surat keterangan kerja untuk memastikan Posisi, Jabatan dan Tempat kerja Nasabah.

\section{Mengetahui Perhitungan Pembayaran KPR} BTN Bersubsidi iB di Bank Tabungan Negara Kantor Cabang Syariah Bogor.

Berikut contoh perhitungan pembayaran KPR BTN Bersubsidi iB pada BTN Kantor Cabang Syariah Bogor :
Bapak RUDI seorang Manajer Operasional Retail PT. Maju Pesat Tbk. dengan total penghasilan perbulan sebesar Rp. 4.000.000,-. Bapak RUDI mengajukan permohonan kepada BTN Kantor Cabang Syariah Bogor untuk membeli rumah pada Perum Bogor Indah Permai Blok E No. 77 dengan Plafond sebesar Rp. 133.000.000,-, margin BTN Kantor Cabang Syariah Bogor sebesar $5 \%$, Jangka Waktu 20 tahun dan Angsuran perbulan sebesar Rp. 1.108.333,jangka waktu pembiayaan 240 bulan.

$$
\begin{aligned}
\text { Hitungan Angsuran } & =\frac{\text { Perbaiki Penghasilan ( Fix Income })}{(12 \text { bulan } \times \text { Jangka Waktu })} \\
& =\frac{\text { Rp. } 133.000 .000_{2}-+\left(\text { Rp. } 133.000 .000_{2}-\times 5 \% \times 20 \text { tahun }\right)}{(12 \times 20)} \\
& =\frac{\text { Rp. } 133.000 .000_{2}-+ \text { Rp. } 133.000 .000_{-}-}{240} \\
& =\text { Rp. } 1.108 .333_{--}
\end{aligned}
$$

\section{Kesimpulan dan Saran}

1. Cara Divisi / Bagian financing analyst menganalisis Kemampuan ( Capacity) Nasabah dalam mengambil produk pembiyaan KPR Bersubsidi iB dengan :

a. Melihat KTP untuk mengetahui karakter nasabah dari hasil IDEB / BI Checking / ID BI dan untuk mengetahui jumlah angsuran perbulan berdasarkan pembiayaan yang telah diterima sebelumnya.

b. Melihat KK untuk mengetahui jumlah tanggungan, sehingga bisa memperkirakan pengeluaran pribadi / keluarga dalam 1 bulan. c. Melihat buku nikah untuk mengetahui status pernikahan.

d. Melihat Slip Gaji + copy rekening koran untuk mengetahui dan memastikan Nominal Gaji / Penghasilan yang diterima perbulan.

e. Melihat Surat keterangan kerja untuk memastikan Posisi, Jabatan dan Tempat kerja Nasabah.

2. Cara Divisi / Bagian financing analyst menghitung simulasi angsuran KPR BTN Bersubsidi iB dengan menggunakan Perbaiki Penghasilan ( Fix Income ), yaitu: 


\section{$\underline{\text { Plafond + (Plafond x Margin x Jangka Waktu) }}$ \\ ( 12 bulan $x$ Jangka Waktu )}

\section{Daftar Pustaka}

Lukman Dandawijaya. 2001. Manajemen Perbankan Syariah. Ghalia Indonesia. Jakarta.

Soemitra, Andri. 2010. Bank \& Lembaga Keuangan Syariah. Kencana Prenada Media Group. Jakarta.

Drs. Ismail, MBA., Ak. 2011. Perbankan Syariah. Edisi Pertama, Cetakan ke satu. Kencana Prenada Media Group, Jakarta.
Suzanna Hardjono, ST. 2008. Mudah Memiliki Rumah Idaman Lewat KPR. PT. Galangpress Media Utama.

Muhammad. 2011. Manajemen Bank Syariah (Edisi revisi cetakan kedua). UPPSTIM YKPN.

Ismail. 2011. Perbankan Syariah. Kencana.Jakarta.

Husein Umar. 2000. Research Methods and Banking. Gramedia. Jakarta. 